\title{
Certainty Factor Method for Neurological Disease Diagnosis Based on Symptoms
}

\author{
Anugrah Syauqi Yanuar ${ }^{1}$, Elyza Gustri Wahyuni ${ }^{2}$, Dian Tri Wiyanti ${ }^{3}$ \\ \{13523122@students.uii.ac.id ${ }^{1}$, elyza@uii.ac.id², diantriwiyanti@mail.unnes.ac.id $\left.{ }^{3}\right\}$
}

Department of Informatics, Industrial Technology Faculty, Universitas Islam Indonesia Sleman, Special Region of Yogyakarta, Indonesia ${ }^{12}$, Mathematics Department, Faculty of Math and

Science, Universitas Negeri Semarang, Semarang, Central Java, Indonesia ${ }^{3}$

\begin{abstract}
An illness accompanied by symptoms. Symptoms of one disease are often similar to other symptoms. It makes a person feel confused and panicked by the symptoms he felt. They are also difficult to determine the type of their illness. Thus, the patient does not know well about early prevention of their disease. This can be risky, sooner or later. One way to solve this problem is to create a web-based expert system. In this research, expert system made using Certanty Factor method. The expert system was chosen because it was able to diagnose the disease like an expert or neurologist. This system can provide an explanation of it and attemption of handle, whenever and wherever. This system also has compliance with the provisions and rules made by a medical expert to diagnose the disease. System testing has been carried out with experts, and proven successful.
\end{abstract}

Keywords: expert system, certainty factor, neurological disease.

\section{Introduction}

The human nervous system consists of millions of nerve fibers with interconnected nerve cells. This system controls several functions, including brain growth and development, perception, idea, emotion, and movement of balance. This vital system will disrupt the body's activity if it is damaged, even causing temporary or permanent paralysis. Symptoms of nerve disorders depend on the type of nerve that is disturbed and damaged. Factors that cause neurological diseases are heredity, imperfect nerve development, damaged or dead nerve cells, blood vessel disorders to the brain, injury, cancer, seizures, and infections. Some neurological diseases that often occur are Bell Palsy, Vertigo, Mild Stroke, Heavy Stroke, Spinal Nerve Injury (Cord Injury), Parkinson's, and Spinal Nerve Disease[1].

Nerve disease patients are often confused with early symptoms occur. This is because the symptoms of these diseases are similar and difficult to distinguish. In the medical field, the use of technology has become common thing. Technology is very helpful in all aspects such as data archiving and information media. One of the trends of today's technology is the Expert System. Expert systems are computer-based systems that use knowledge, facts, and reasoning techniques in solving problems that are usually only solved by an expert in a particular field[2].

ICCSET 2018, October 25-26, Kudus, Indonesia

Copyright (C) 2018 EAI

DOI 10.4108/eai.24-10-2018.2280500 


\subsection{Related Work}

Related Research. Previous research by Ayuda Aninda in 2016. The study discussed the diagnosis based on cough symptoms using an android-based application using the Certainty Factor method[3]. There are weaknesses in this study. There is no admin page for experts to do data analysis, diseases and rules. Then the system cannot explain the meaning of the diagnosis. While the advantages of this system are that it can produce an accurate disease diagnosis like experts, using the Certainty Factor method.

Other related research was conducted by Anis Pratiwi in 2016. This research discussed the expert system of diagnosis of Acute Respiratory Infection using the Certainty Factor method[4]. This research has weaknesses. In the developed system, there is no IF-THEN reasoning that adopts expert knowledge regarding the provision of symptoms for disease. So that the process of disease diagnosis in the system is only based on knowledge with the MB and MD values in each symptom. While the advantage is that the diagnostic process is calculated using the Certainty Factor method which always concludes quite accurate results with the percentage of results.

The third study discusses the expert system of skin diseases in humans by using the webbased Certainty Factor method. The weakness is that, when inputting symptoms on the system, there are many symptoms that are not divided into sections. Making it less efficient when users perform a search based on the symptoms. While the advantages are the application of the Certainty factor method in drawing conclusions in accordance with the results carried out by experts[5].

\subsection{Our Contribution}

Contribution. This expert system research aims to generating early diagnosis of neurological diseases based on the symptoms felt by the user. The diagnosis of disease is displayed in the form of information that is easily understood. This expert system can help the general public as users to make initial diagnoses related to the symptoms of neurological diseases that they feel, which can be done anytime and anywhere. In addition, users also get information about neurological diseases and their types. Users can make an early treatment effort and any further action regarding the results of the diagnosis of neurological diseases. Another contribution is that this expert system can recommend a diagnostic results to experts.

\section{System Analysis}

The method that will be used in this research is certainty factor. Symptoms are facts or hypotheses which, if there are additional new data, will cause inconsistencies. Therefore, each symptom will be given the value of MB (Measure Belief) and MD (Measure Disbelief) in order to avoid inconsistency in determining the certainty level of diagnosis.

\subsection{Inference Engine}

Inference Engine. Then the basic method of the inference engine used is forward chaining, which is the reasoning process of a problem that requires a set of data or facts. A best 
conclusion can be drawn from this fact and used as a solution. In making a diagnosis of neurological disease, it is necessary to have symptoms based on the facts available to create a knowledge base rule. From the rules of knowledge base can be obtained the results of diagnosis, such as the type of disease suffered by patients. The following figure is a forward chaining inference model on an expert system for diagnosing neurological diseases based on established rules.

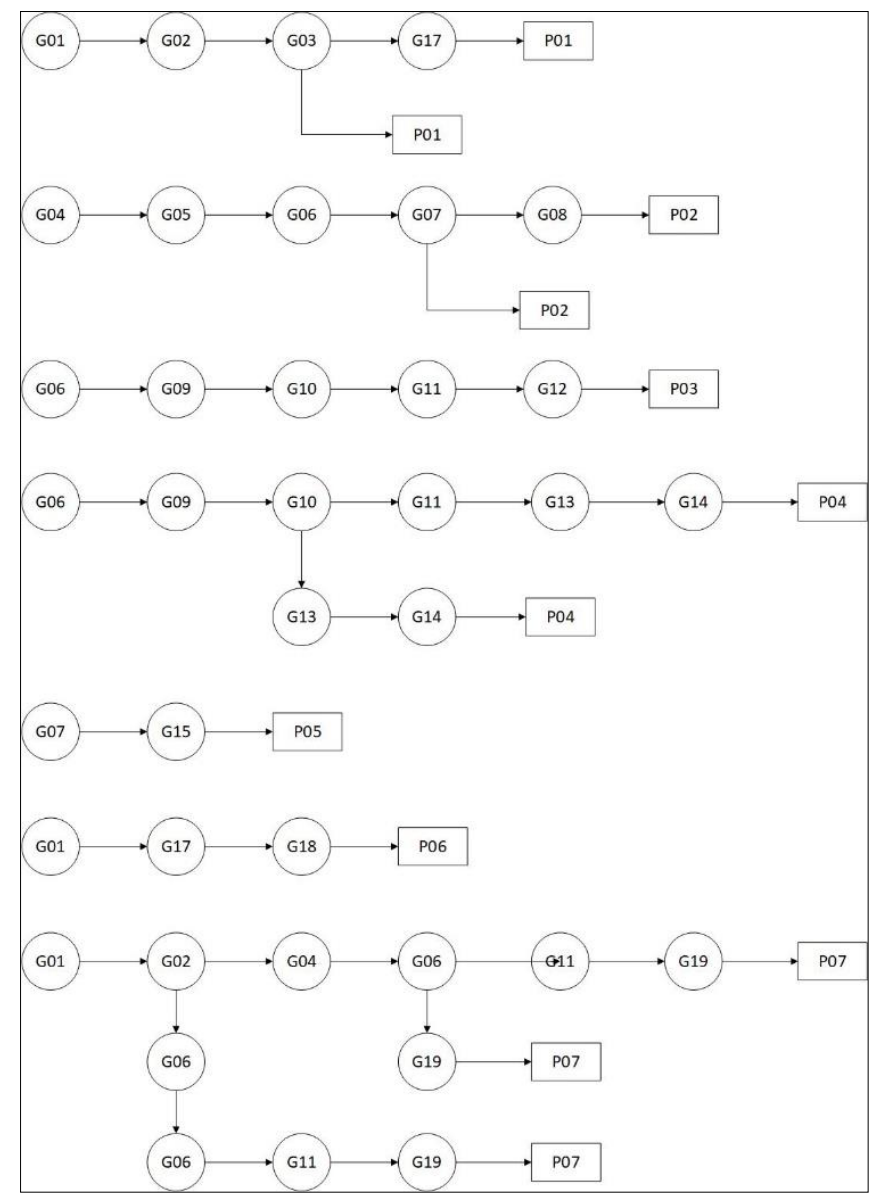

Fig. 1. Forward Chaining Inference Modelling for Neurological Disease Diagnosis Expert System.

\subsection{Certainty Factor}

Certainty Factor. Certainty Factor (CF) is known as a method that shows a measure of certainty and value of truth against a fact or rule[6]. The notation of the certainty factor is as follows :

$$
\mathrm{CF}[\mathrm{h}, \mathrm{e}]=\mathrm{MB}[\mathrm{h}, \mathrm{e}]-\mathrm{MD}[\mathrm{h}, \mathrm{e}]
$$


$\mathrm{CF}[\mathrm{h}, \mathrm{e}]$ is a Certainty Factor, MB [h, e] is a measure of confidence in the hypothesis $\mathrm{h}$, if evidence e is given (between 0 and 1 ), and MD [h, e] is a non-confidence measure of evidence $\mathrm{h}$, if evidence e is given (between 0 and 1 ).

Certainty factor method is used to make decisions based on $\mathrm{MB}$ and $\mathrm{MD}$ on each symptom to measure the level of trust $(\mathrm{CF})$. The $\mathrm{MB}$ and MD relation table for neurological symptoms can be seen in Table 1 .

Table 1. Relation Table of MB and MD Values to Neurological Diseases.

\begin{tabular}{|c|c|c|c|c|c|c|c|c|c|c|c|c|c|c|}
\hline \multirow{3}{*}{ Symptom } & \multicolumn{14}{|c|}{ Disease } \\
\hline & \multicolumn{2}{|c|}{$\mathrm{P} 01$} & \multicolumn{2}{|c|}{ P02 } & \multicolumn{2}{|c|}{$\mathrm{P} 03$} & \multicolumn{2}{|c|}{ P04 } & \multicolumn{2}{|c|}{ P05 } & \multicolumn{2}{|c|}{ P06 } & \multicolumn{2}{|c|}{ P07 } \\
\hline & MB & MD & MB & MD & MB & MD & MB & MD & MB & MD & MB & MD & MB & $\mathrm{MD}$ \\
\hline G01 & 0,85 & 0,02 & - & - & - & - & - & - & - & - & 0,83 & 0,03 & 0,86 & 0,02 \\
\hline G02 & 0,98 & 0,01 & - & - & - & - & - & - & - & - & - & - & 0,85 & 0,04 \\
\hline G03 & 0,86 & 0,02 & - & - & - & - & - & - & - & - & - & - & - & - \\
\hline G04 & - & - & 0,85 & 0,1 & - & - & - & - & - & - & - & - & 0,62 & 0,09 \\
\hline G05 & - & - & 0,85 & 0,3 & - & - & - & - & - & - & - & - & - & - \\
\hline G06 & - & - & 0,62 & 0,04 & 0,94 & 0,03 & 0,80 & 0,04 & - & - & - & - & 0,65 & 0,08 \\
\hline G07 & - & - & 0,45 & 0,06 & - & - & - & - & 0,92 & 0,06 & - & - & - & - \\
\hline G08 & - & - & 0,86 & 0,2 & - & - & - & - & - & - & - & - & - & - \\
\hline G09 & - & - & - & - & 0,96 & 0,02 & - & - & - & - & - & - & - & - \\
\hline G010 & - & - & - & - & 0,96 & 0,01 & - & - & - & - & - & - & - & - \\
\hline G011 & - & - & - & - & 0,98 & 0,01 & - & - & - & - & - & - & 0,87 & 0,01 \\
\hline G012 & - & - & - & - & 0,92 & 0,04 & - & - & - & - & - & - & - & - \\
\hline G013 & - & - & - & - & - & - & 0,97 & 0,03 & - & - & - & - & - & - \\
\hline G014 & - & - & - & - & - & - & 0,82 & 0,02 & - & - & - & - & - & - \\
\hline G015 & - & - & - & - & - & - & - & - & 0,86 & 0,02 & - & - & - & - \\
\hline G016 & - & - & - & - & - & - & - & - & 0,95 & 0,01 & - & - & - & - \\
\hline G017 & - & - & - & - & - & - & - & - & - & - & 0,94 & 0,05 & - & - \\
\hline G018 & - & - & - & - & - & - & - & - & - & - & 0,92 & 0,04 & - & - \\
\hline G019 & - & - & - & - & - & - & - & - & - & - & - & - & 0,6 & 0,3 \\
\hline
\end{tabular}

\section{Implementation and Testing}

Implementation of the system is the process of testing to see whether the system can work well as designed and the system is completely feasible to use. System testing is divided into two stages and carried out by experts.

\subsection{Trial Process by Expert}

Trial by Expert. To conduct a trial, a sample of symptoms and diseases is taken based on the symptoms and disease data contained in the system. The following is a sample of symptoms carried out. 
Table 2. Examples of Symptoms in Case Study.

\begin{tabular}{cl}
\hline Symptom Code & \multicolumn{1}{c}{ Symptom } \\
\hline G01 & Partial paralysis in the facial muscles characterized \\
G02 & by difficulty moving in certain parts \\
G03 & Limb weakness \\
G07 & Tough talk and feel numb when talking \\
\hline
\end{tabular}

In the case study contained in the table above, the expert analyses the symptoms. According to experts, the disease that arises based on these symptoms is a stroke.

\subsection{Trial Process by System}

Trial by System. Diagnosis of the disease using the system is done by inputting the symptoms first. Then the system will process input data and perform calculations. The calculation process in the system uses the certainty factor method that has been applied during system development. Users should choose some of the symptoms displayed.

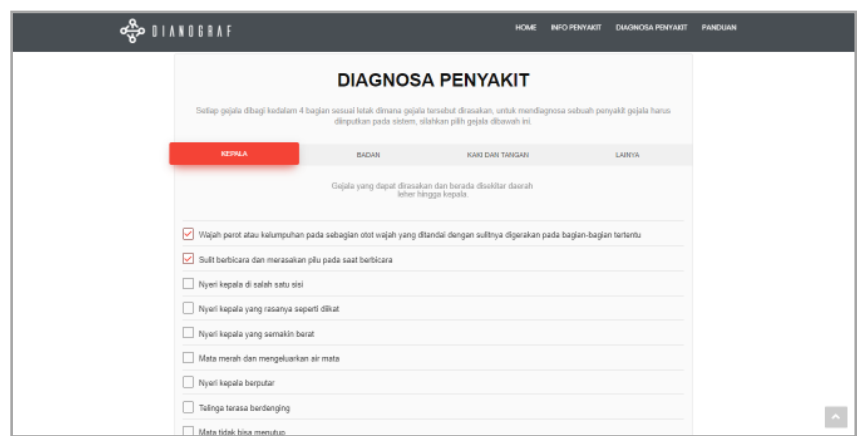

Fig. 2. Input Proces in the System.

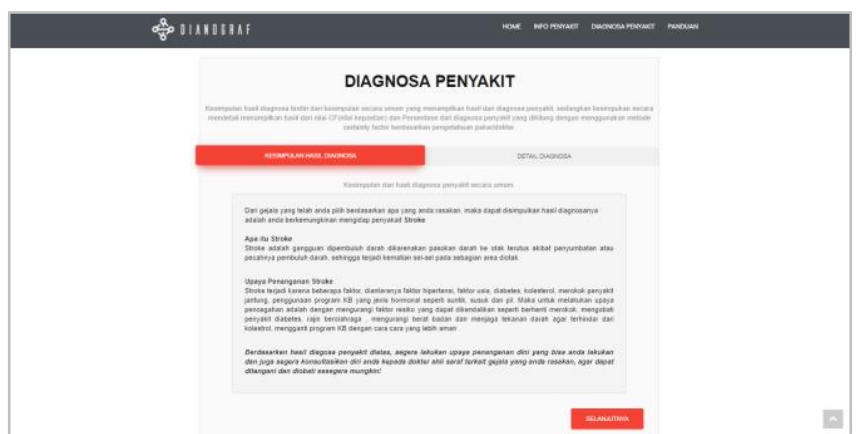

Fig. 3. Diagnosis Results by System. 


\section{Conclusion}

After the disease diagnosis testing process with the same list of symptoms, results are obtained such as Table 2 and Figure 3. So that it can be concluded that disease diagnoses are carried out by experts manually and the system has the same and accurate results.

Certainty Factor highly precise method used to apply into the development of nerve disease diagnosis expert system. This is because the method used can provide the same results as the diagnostic process performed by the expert / doctor, manual calculation, or by the system.

\section{Referensi}

[1] Alodokter, “Gejala, Penyebab dan Mengobati," 2016. [Online]. Available: http://www.alodokter.com/gonore.

[2] D. Aziz, E. F., Damiri, D. J., Destiani, "Perancangan sistem pakar diagnosis penyakit syaraf pada wajah berbasis web," J. STT-Garut All Right Reserv., pp. 1-8, 2014.

[3] K. S. Aninda, A.D., "Diagnosis Penyakit Berdasarkan Gejala Batuk Berbasis Android. Seminar Nasional Informatika Medis (SNIMed).”Yogyakarta, 2016.

[4] E. . ratiwi A., Wahyuni, "Sistem Pakar Diagnosis ISPA pada Balita dengan Metode Certainty Factor," Semin. Nas. Inform. Medis, 2016.

[5] D. Parhusip, J., Pranatawijaya, V. H., \& Putrisetiani, "Sistem Pakar Diagnosa Penyakit Jantung Menggunakan Metode Certainty Factor Berbasis Web," Semin. Nas. Inform., pp. 46-52, 2012.

[6] S. Kusumadewi, Artificial Intelligence (Teknik dan Aplikasinya). Yogyakarta: Graha Ilmu, 2003. 